\title{
BISMUTITE OF THE GRANITE PEGMATITES OF ZAMBEZIA, MOZAMBIQUE
}

\author{
Th. G. Sahama and Martti Lehtinen \\ University of Helsinki, Finland
}

\begin{abstract}
This paper deals with the general mineralogy of bismutite from Zambezia, Mozambique. Three new chemical analyses are given. It is suggested that the deficiency in $\mathrm{CO}_{2}$ is balanced by a certain water content. DTA and thermobalance data are given. Electron diffraction data indicate the mineral to be pseudo-tetragonal and orthorhombic with $a_{0} \sim b_{0}=5.473 \AA$. The orthorhombic symmetry could be attributed to the ordering of the $\mathrm{CO}_{3}$ groups.
\end{abstract}

\section{Introduction}

On several visits to a number of granite pegmatite localities in the district of Zambezia, Mozambique, the senior author was privileged to receive a series of specimens of the bismuth minerals commercially produced by the pegmatite mines. The bismuth ore consists mainly of »bismuth ocher» and, to a subordinate degree, of metallic bismuth. The specimens were given by the people operating the mines and, accordingly, their detailed field association is not known. Preliminary inspection in the laboratory confirmed the bismuth ocher to represent bismutite. Because accurate mineralogical information concerning the Zambezia bismutite is virtuaally non-existent in the literature, the mineral was subjected to a closer study. The results are reported in this paper.

\section{General characteristics}

Bismutite was available as irregular or rounded pieces sometimes associated with quartz, in sev- eral cases showing alternating narrow bismutite and quartz lamellae. The material is more or less friable and porous with cavities detectable on breaking the specimens. The cavities contain muscovite or heavily altered micaceous material and quartz. The color of the bismutite varies from honey yellow to dark grey or even greenish. The variation of the color is evidently caused by the varying aggregation of the material and by pigment. The bismutite masses are often cut by thin black veinlets of poorly crystallized hard manganomelane.

The bismutite is of secondary crystallization. Many specimens exhibit a pronounced acicular texture, an example of which is illustrated in Fig. 1. This figure shows pale colored yellowish remnants of acicular bismutite cut through by a later crystallization of dark grey bismutite mesostasis.

No difference in powder pattern was detected between the yellow and the dark portions of bismutite. Some other specimens, in which no traces of any acicular texture can be seen, exhibit on cut and polished surfaces pale colored ghost- 


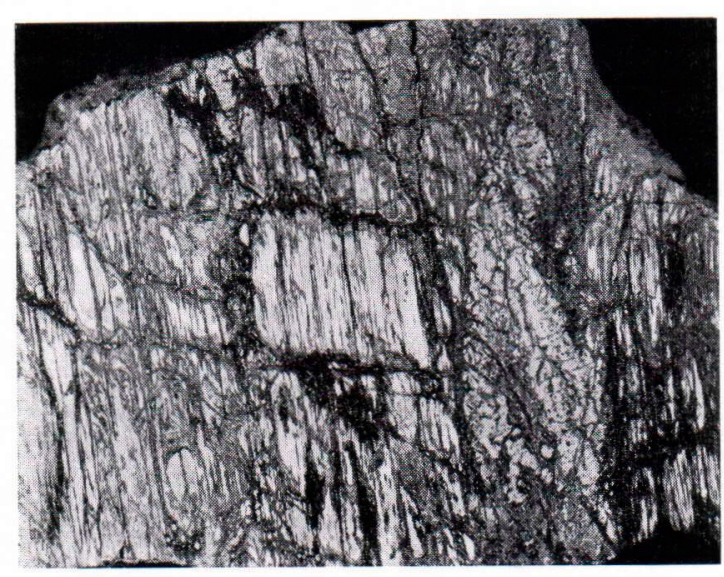

A

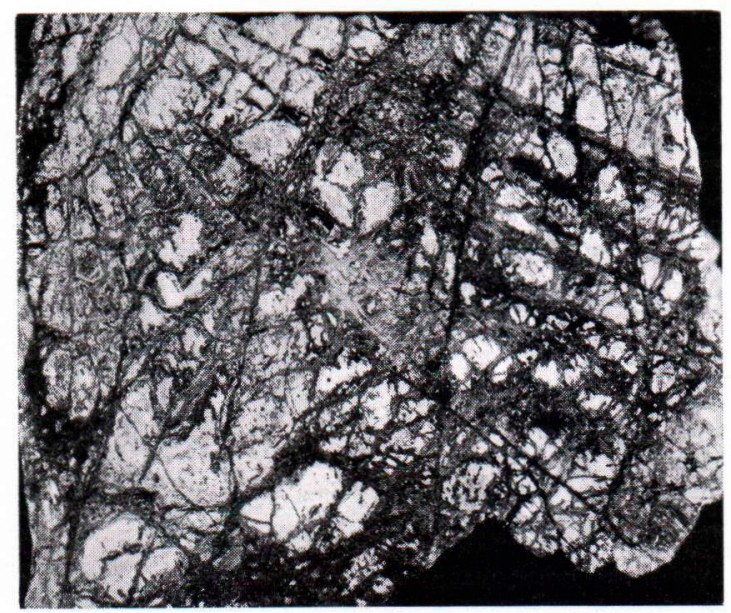

B

FIG. 1. Polished surfaces of bismutite specimen No. 34, Muiane Mine, Mozambique. Illustrating the acicular texture. A. Section parallel to the elongation. Magnification $2 \mathrm{x}$. B. Section perpendicular to the elongation. Magnification $3 \mathrm{x}$.

like remnants lying in a slightly darker massive mesostasis. A third kind of specimen represents homogeneous massive material without relictic features. This tectural series is taken as a proof that, during the last stages of the crystallization of the pegmatite body, bismutite is easily recrystallized and mobilized. The acicular bismutite represents early stages in the alteration of bismuthinite in which the original bismuthinite texture has been preserved. Actually, unaltered bismuthinite is also known from some of the Zambezia pegmatites (for example from Muiane and Maridge). Poorly developed pseudomorphic crystal forms often found in the bismutite material show prismatic habit characteristic of bismuthinite.

Being very fine-grained (grain size less than 1 micron) the bismutite material is not suitable for determination of optical constants nor for single crystal X-ray work. Electron microscopic study revealed the grains to be of a platy habit parallel to (001).

The density of specimen No. 24 was measured with a Notari volumeter on ca. $25 \mathrm{~cm}^{3}$ of the powdered material yielding $\mathrm{d}=8.11 \pm 0.05$. This value compares with 8.25 calculable on the basis of the composition of this specimen (Table 1). For the synthetic $\mathrm{Bi}_{2} \mathrm{CO}_{5}$, Lagercrantz and Sillén (1947) give the following values: $\mathrm{d}_{\text {meas }}$. $=8.15$ and $\mathrm{d}_{\text {calc }}$. $=8.28$. For a Russian bismutite, Nefedov (1956) gives $d=8.32$. In older literature reviewed by Frondel (1943), the values given for the densities of natural bismutite are usually lower and quite variable. It is not known how much the porosity of the materials was responsible for the low values.

\section{Chemical compostition}

Three bismutite specimens without visible impurities were selected for chemical analysis. The results are presented in Table $1 \mathrm{~A}$. In addition to the cations listed in the table, minute traces of only $\mathrm{Ag}$ and Te were detected with the $\mathrm{XRF}$ technique in the range from $\mathrm{Mg}$ to $\mathrm{U}$. The specimens analyzed were studied by microprobe. X-ray scanning images of specimen No. 34 which represents the least recrystallized bismutite revealed a strong enrichment of $\mathrm{Pb}, \mathrm{Sb}$ and $\mathrm{Fe}$ in aggregates free from $\mathrm{Bi}$. These aggregates are softer than bismutite and too small (maximum 
TABLE 1.

Chemical composition of bismutite from granite pegmatite, Zambezia, Mozambique.

1. Specimen No. 34, Muiane Mine. Acicular texture. Greyish yellow relictic portions cut through by a dark mesostasis Illustrated in Fig. 1.

2. Specimen No. 24, Marropino Mine. Pulverulent mass containing light yellow relictic portions in a somewhat darker greyish mesostasis.

3. Spesimen No. 17, Marropino Mine. Honey yellow pulverulent mass.

A. Results of analyses by T. Koljonen.

\begin{tabular}{|c|c|c|c|}
\hline & 1. & 2. & 3. \\
\hline 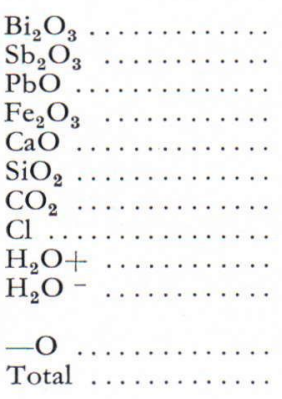 & $\begin{array}{c}90.57 \% \\
0.24 \\
0.08 \\
0.18 \\
0.06 \\
0.39 \\
8.33 \\
\text { trace } \\
0.50 \\
0.11\end{array}$ & $\begin{array}{c}90.92 \% \\
0.01 \\
0.15 \\
0.06 \\
\text { trace } \\
0.16 \\
7.99 \\
\text { trace } \\
0.56 \\
0.08\end{array}$ & $\begin{array}{c}89.58 \% \\
0.01 \\
1.51 \\
0.34 \\
0.44 \\
0.65 \\
5.87 \\
0.22 \\
0.90 \\
0.60 \\
100.12 \\
0.05 \\
100.07\end{array}$ \\
\hline
\end{tabular}

B. Calculated free from impurities.

\begin{tabular}{l|c|c|c}
\hline & 1. & 2. & 3. \\
\hline $\mathrm{Bi}_{2} \mathrm{O}_{3} \ldots \ldots \ldots \ldots \ldots$ & $91.17 \%$ & $91.44 \%$ & $93.50 \%$ \\
$\mathrm{CO}_{2} \ldots \ldots \ldots \ldots \ldots$ & 8.33 & 8.00 & 5.55 \\
$\mathrm{H}_{2} \mathrm{O}+\ldots \ldots \ldots \ldots$ & 0.50 & 0.56 & 0.95
\end{tabular}

size ca. $0.05 \mathrm{~mm}$ ) to be isolated for powder pattern work. Accordingly, the $\mathrm{Pb}, \mathrm{Sb}$ and $\mathrm{Fe}$ shown by the chemical analyses do not belong to the bismutite structure. The phases in which these cations are contained cannot be identified. On the other hand, no enrichment of $\mathrm{Ca}$ and $\mathrm{Cl}$ in any spots were found. For calculating the compositions of Table $1 \mathrm{~B}$ the following assumptions were considered reasonable for specimen No. 34: $\mathrm{SiO}_{2}$ present as quartz; $\mathrm{Fe}_{2} \mathrm{O}_{3}$ as oxide; $\mathrm{PbO}, \mathrm{Sb}_{2} \mathrm{O}_{3}, \mathrm{CaO}$ as carbonates; $\mathrm{Cl}$ as bismoclite. In specimens Nos. 17 and 24, respresenting more advanced stages of bismutite recrystallization, no enrichment of the minor elements were detected in any spots of the specimens. The corrections employed for specimen No. 34 were also applied to these two specimens.
The new analyses of Table 1B together with the analyses of »bismutite» and »bismutosphaerite» listed by Hintze (1930) were plotted in Fig. 2 which illustrates the molecular ratio $\mathrm{Bi}_{2} \mathrm{O}_{3}$ : $\mathrm{CO}_{2}: \mathrm{H}_{2} \mathrm{O}$. The analyses were corrected for $\mathrm{Pb}$, Ca etc. As was shown by Frondel (1943), both bismutite and bismutosphaerite give powder pattern identical to that of synthetic $\mathrm{Bi}_{2} \mathrm{CO}_{5}$. The water content shown by many analyses was considered by him non-essential. The chemical analyses of natural bismuth carbonate available in literature are mostly old and not too much emphasis should be laid on a single analysis. If all water were entirely non-essential, the points in Fig. 2 would cluster around the join $\mathrm{Bi}_{2} \mathrm{CO}_{5}-\mathrm{H}_{2} \mathrm{O}$. They do, however, show a sta tistical deviation from this join towards the 


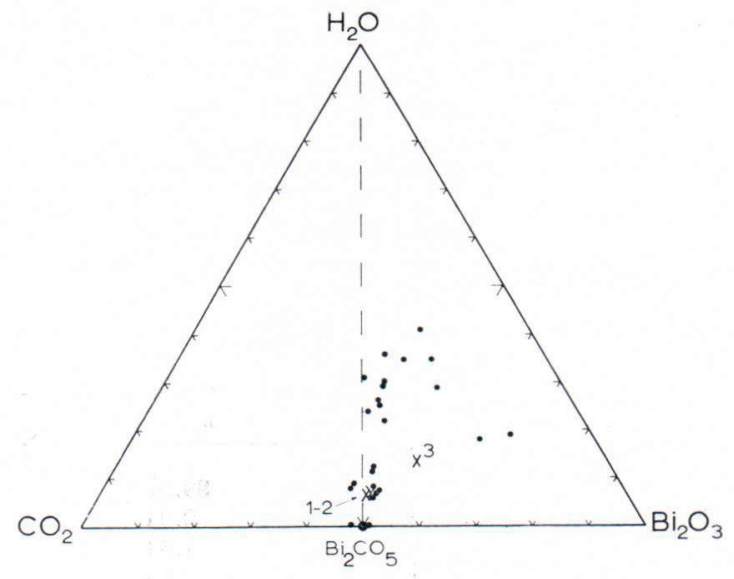

FIG. 2. Variation of the molecular ratio $\mathrm{Bi}_{2} \mathrm{O}_{3}: \mathrm{CO}_{2}: \mathrm{H}_{2} \mathrm{O}$ in natural bismutite. Points: 'bismutite'

and 'bismutosphaerite' according to Hintze. Crosses: specimens of Table $1 \mathrm{~B}$.

$\mathrm{Bi}_{2} \mathrm{O}_{3}$ apex. The same trend is shown also by specimen No. 17 (anal. 3 in Table 1) in which the deficiency in $\mathrm{CO}_{3}$ was carefully tested. In that specimen, $\mathrm{Bi}_{2} \mathrm{O}_{3}$ and $\mathrm{j}_{2}$ are definitely not in a stoichiometric ratio. It seems that not all the water in bismutite can be considered entirely non-essential, but that the deficiency in $\mathrm{CO}_{2}$ found in some bismutite samples is balanced by a certain water content.

\section{Thermal behavior}

A DTA and thermobalance run was extended up to $600^{\circ} \mathrm{C}$ for the specimen No. 17 (Fig. 3). The decomposition of the material begins at $400^{\circ} \mathrm{C}$, the DTA curve reaches an endothermic maximum at $520^{\circ} \mathrm{C}$ and the thermobalance curve drops down to a constant level at ca. $580^{\circ} \mathrm{C}$. In the temperature range $400^{\circ}-580^{\circ} \mathrm{C}$ the loss of $\mathrm{CO}_{2}+\mathrm{H}_{2} \mathrm{O}$ is continuous. Frondel (1943) found a continuous weight loss up to ca. $290^{\circ} \mathrm{C}$ where the loss rises abruptly. Because his determinations were made by heating to constant weight, his curves are not immediately comparable with the thermobalance run illustrated in Fig. 3 in which virtually no weight loss is ob-

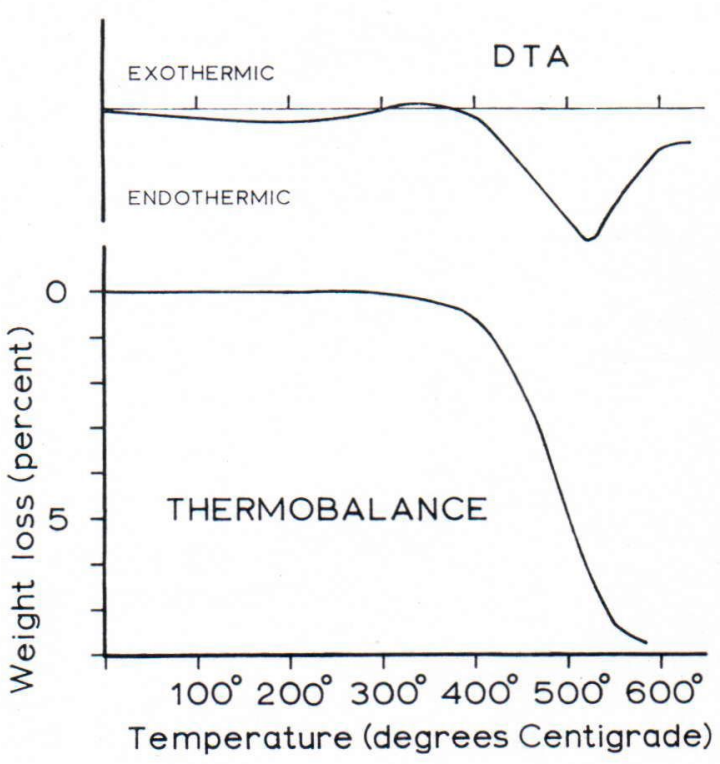

FIG. 3. DTA and thermobalance runs of bismutite, specimen No. 17.

served at $290^{\circ} \mathrm{C}$. If all the water were just capillary moisture, the thermobalance curve which indicates the loss of $\mathrm{CO}_{2}+\mathrm{H}_{2} \mathrm{O}$ could be expected to drop more discontinuously. The DTA curve is in fairly good agreement with the results obtained by Beck (1950) on three unalyzed American bismutite specimens. High temperature $\mathrm{X}$-ray powder work showed the DTA peak at $250^{\circ} \mathrm{C}$ to reflect the bismutite $\rightarrow$ bismite transformation.

\section{Crystallography}

Powder patterns of a number of specimens (Philips Norelco, $\mathrm{Cu}$ radiation, Si standard) revealed no measurable variation in the location and intensity of the reflections. The powder pattern (Table 2, with both tetragonal and orthorhombic indices) contains no extra lines and is virtually identical with that of synthetic $\mathrm{Bi}_{2} \mathrm{CO}_{5}$ (Largercrantz and Sillén, 1947; recalculated into a more convenient form in ASTM 
TABle 2.

Powder pattern of natural bismutite from Marropino Mine (specimen No. 17), Zambezia, Mozambique.

\begin{tabular}{r|r|r|r}
\hline $\begin{array}{c}\text { hkl } \\
\text { (tetragonal) }\end{array}$ & $\begin{array}{c}\text { hkl } \\
\text { (orthorhombic) }\end{array}$ & $\mathrm{d}$ & $\mathrm{I}$ \\
\hline 002 & 002 & 6.85 & 15 \\
101 & 111 & 3.724 & 30 \\
004 & 004 & 3.422 & 14 \\
103 & 113 & 2.953 & 100 \\
110 & 200 & 2.737 & 41 \\
112 & 202 & 2.542 & 6 \\
006 & 006 & $2.280 \mathrm{~b}$ & 13 \\
114 & 204 & 2.137 & 25 \\
200 & 220 & 1.9354 & 20 \\
202 & 222 & 1.8620 & 6 \\
116 & 206 & $1.7502 \mathrm{~b}$ & 22 \\
211 & 311 & 1.7178 & 11 \\
204 & 224 & 1.6843 & 9 \\
213 & 313 & $1.6184 \mathrm{~b}$ & 30 \\
206 & 226 & 1.4760 & 9 \\
109 & 119 & 1.4166 & 9 \\
00.10 & 00.10 & 1.3688 & 7
\end{tabular}

b Line broad.

card No. 4-0662). The unit cell dimensions calculated for the tetragonal cell are: $a_{0}=3.870$ $\pm 0.002 \AA$ and $c_{\circ}=13.697 \pm 0.005 \AA$.

The electron diffraction pattern of bismutite specimen No. 17 exhibits the strong reflections of the tetragonal body-centered cell. The photographs were calibrated using cubic TlCl with $a_{\circ}=3.842 \AA$ as an internal standard. In addition, the electron diffraction photographs reveal some few weak reflections indicating a doubling of the tetragonal $a$ - and $b$-axes. Finally, most of the photographs contain rows of extremely weak reflections corresponding to a superstructure with a fivefold period along one of the two diagonals, (110) or (110), of the tetragonal cell. Along these rows very faint continuous streaks are visible. The weak reflections of the electron diffraction photographs are not detectable in X-ray powder pattern.

The crystal structure of $\mathrm{Bi}_{2} \mathrm{CO}_{5}$ has been determined by Lagercrantz and Sillén (1947) using synthetic material. These authors arrived at a tetragonal body-centered cell (space group $\mathrm{I} 4 / \mathrm{mmm}$ ) with $a_{\circ}=3.867 \AA$ and $c_{\circ}=13.686 \AA$ (both $\pm 0.1 \%$ ) and with the centers of the
$\mathrm{CO}_{3}$ groups at $00 \frac{1}{2}$. The $\mathrm{CO}_{3}$ groups are parallel to (110) or $(1 \overline{1} 0)$. The rotation or orientation of neighboring $\mathrm{CO}_{3}$ groups must be coupled to some extent. No superstructure was detected in the rotation and Weissenberg photographs. No optical data are given. In a pegmatite from Russian Karelia, Nefedov (1956*) found exceptionally large platy bismutite single crystals (up to $0.1 \mathrm{~mm}$ ) and was able to study the mineral both optically and by $\mathrm{X}$-ray methods. He also found a tetragonal unit cell with $a_{\circ}=3.87 \AA$ and $c_{\circ}=13.69 \AA$. The mineral is, however, optically biaxial with $2 \mathrm{~V}=45^{\circ}$ and the optic axial plane parallel to a diagonal of the tetragonal cell. $\mathrm{He}$ concluded that the mineral is orthorhombic, the old tetragonal body-centered cell being transformed to the new orthorhombic cell by the operation of matrix 110/110/001. The orthorhombic space group would be $F m m m$ with $a$ and $b$-parameters $-5.44 \AA$. The plates often exhibited twinning on (110).

Bismuth represents the only heavy atom in the bismutite structure and, consequently, has the strongest influence upon the intensities of the reflections. The data by Lagercrantz and Sillén indicate no deviation of the positions of the $\mathrm{Bi}$ atoms from a body-centered tetragonal symmetry. Single crystal X-ray photographs of ordinary exposure disclose only a tetragonal cell with $a_{\circ}=3.87 \AA$. Together with the optical criteria presented by Nefedov, the true orthothombic symmetry of bismutite is supported by the extra weak reflections of the electron diffraction photographs of the Marropino specimen No. 17. Thus, the parameters of the orthorhombic unit cell are: $a_{\circ}-b_{\circ}=\sqrt{2} \times 3.870=5.473$ $\AA$ (5.44 $\AA$ as given by Nefedov for the Russian bismutite), $c_{\circ}=13.697 \AA$. The superstructure corresponds to $a_{\circ}\left(\right.$ or $\left.b_{\circ}\right)=5 \times 5.473 \AA$.

The body-centered tetragonal LagercrantzSillén cell requires a statistically spherical symmetry of the $\mathrm{CO}_{3}$ groups caused by a rotation of

* The original paper has not been available to the authors. Cited according to Min. Abstr., vol. 14, p. 138 and Structure Reports, vol. 20, p. 388. 
the $\mathrm{CO}_{3}$ disks in two planes parallel to (110) or (110) or by a random set of definite orientation in the planes. The lowering of the symmetry from this tetragonal cell to a larger orthorhombic Nefedov cell could be attributed to an ordering of the $\mathrm{CO}_{3}$ groups. Different kinds of ordering either of the rotation plane of the $\mathrm{CO}_{3}$ disks or of the fixed positions of the oxygen atoms in the planes could be constructed. A few possible arrangements of the planes of the $\mathrm{CO}_{3}$ disks are indicated in Fig. 4.

Acknowledgments - The authors are indebted to $\mathrm{Mr}$. E. Lopes da Silva (Lourenço Marques) and to Mr. J. D. Cabral (Morrua, Zambezia) of the specimens studied and to the following gentlemen, all of Finland, for their assistance and advice in the laboratory: Mr T. Koljonen (chemical analyses), Mr. V. Hoffrén and Mr. Y. Vuorelainen (XRF), Mr. R. Räty (electron microscopy), prof. U. Soveri (DTA - thermobalance), Mr J. Siivola (microprobe), Dr. K. Hytönen (high temperature powder pattern), Dr. A. Vorma (critical discussion of the results). Dr. J. D. C. McConnell (Cambridge, UK) is gratefully thanked for advice in interpreting the electron diffraction photographs.
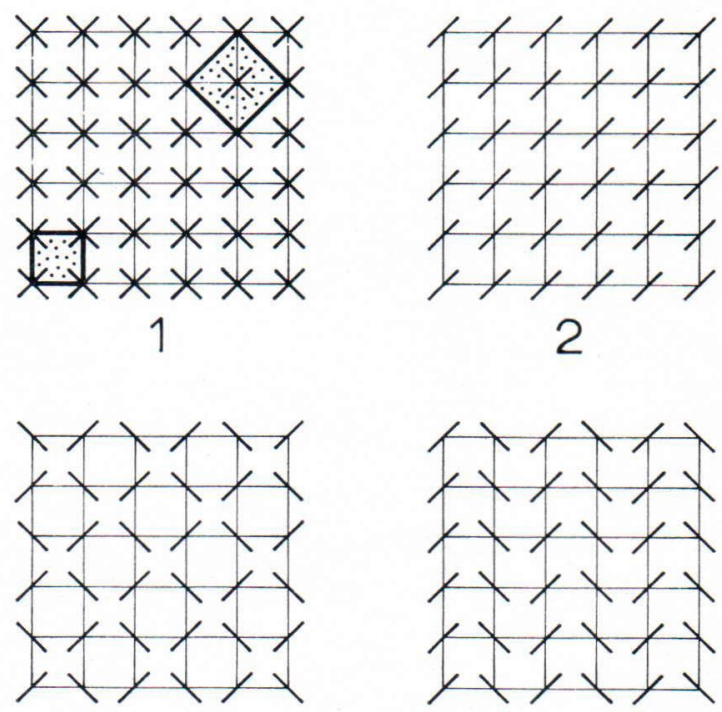

3

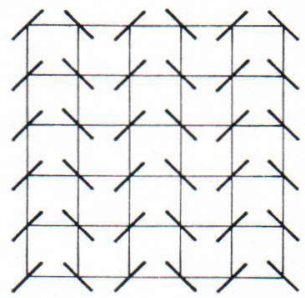

4

FIG. 4. Schematical section of the bismutite structure (perpendicular to the $c$-axis) showing the planes of $\mathrm{CO}_{3}$ groups. 1) Spherical symmetry of the $\mathrm{CO}_{3}$ groups. Bottom left: tetragonal Lagercrantz-Sillén cell. Top right: orthorhombic Nefedov cell. 2-4. Suggestions as to possible kinds of ordering of the planes of the $\mathrm{CO}_{3}$ groups.

\section{REFERENCES}

Beck, Carl W. (1950) Differential thermal analysis curves of carbonate minerals. Amer. Miner., vol. 35, p. 985.

Frondel, Clifford (1943) Mineralogy of the oxides and carbonates of bismuth. Amer. Miner., vol. 28, p. 521.

Hintze, Carl (1930) Handbuch der Mineralogie, Leipzig. $1,3 \mathrm{~A}$, p. 3403 .
Lagercrantz, Åke and Sillén, Lars Gunnar (1947) On the crystal structure of $\mathrm{Bi}_{2} \mathrm{O}_{2} \mathrm{CO}_{3}$ (bismutite) and $\mathrm{CaBi}_{2} \mathrm{O}_{2}\left(\mathrm{CO}_{3}\right)_{2}$ (beyerite). Arkiv f. Kemi, Miner. o. Geol., Bd. 25 A, No. 20.

Nefedov, E. I. (1956) Inform. Sbornik. Vssoyuz. Nauk. - Issledovatel. Geol. Inst., No. 3, p. 80. 